\title{
TiNi 合金の超弾性細管および高弾性細線の曲げ疲労特性*
}

$$
\begin{aligned}
& \text { 戸 伏 壽 昭*1，古市裕 司*1 } \\
& \text { 櫻 木 稔 巴*2, 杉 本 義 樹*3 }
\end{aligned}
$$

\section{Bending Fatigue Properties of a Superelastic Thin Tube and a Highelastic Thin Wire of TiNi Alloy}

\author{
Hisaaki TOBUSH**, Yuji FURUICHI, \\ Toshimi SAKURAGI and Yoshiki SUGIMOTO \\ *4 Department of Mechanical Engineering, Aichi Institute of Technology, \\ 1247 Yachigusa, Yakusa-cho, Toyota-shi, Aichi, 470-0392 Japan
}

\begin{abstract}
Tensile deformation properties and pulsating-plane bending, alternating-plane bending and rotating-bending fatigue properties of a superelastic thin tube (SE-tube) and a highelastic thin wire ( $\mathrm{HE}$-wire) of TiNi alloy were investigated experimentally. The main results obtained are summarized as follows. (1) The stress-strain curve of the SE-tube in tension draws a superelastic hysteresis loop and elastic modulus is $35 \mathrm{GPa}$. Therefore, the SE-tube is superior as a medical catheter tube with flexibility and shape recovery. The stress-strain curve of the $\mathrm{HE}$-wire is close to a straight line up to strain of $4 \%$ and stress of $1500 \mathrm{MPa}$ and elastic modulus is $50 \mathrm{GPa}$. Therefore, the $\mathrm{HE}$-wire is superior as a medical guide wire with flexibility, high pushability and torque transmission performance. (2) With respect to fatigue properties of the SE-tube and the HE-wire in air, the fatigue life in pulsating-plane bending is longer than that in alternating-plane bending and rotating bending. The difference in the fatigue life between alternating-plane bending and rotating bending is small. The relationship between maximum bending strain and the number of cycles to failure in the region of low-cycle fatigue can be expressed by a power function in every bending fatigue. The fatigue life in the body is longer than that in air. (3) The maximum bending strain at the fatigue limit of the SE-tube is $0.8 \%-1.0 \%$ which is close to a starting strain of the stress-induced martensitic transformation. The maximum bending strain at the fatigue limit of the $\mathrm{HE}-$ wire is $0.7 \%-0.8 \%$.
\end{abstract}

Key Words : Shape-Memory Alloy, Fatigue, Bending, Superelasticity, Highelastisity, Tube, Plane Bending, Rotating Bending

\section{1. 精言}

形状記憶合金（shape memory alloy, SMA）は形状記 憶効果 (shape memory effect, SME) と超弾性 (superelasticity, SE) の2 つの特性を示す ${ }^{(1)(5)}$. SME では大き な回復変形と回復応力が利用できる. SE では大きな回 復ひずみおよびひずみエネルギーの貯蔵と散逸仕事を 利用することができる.SMA ではこれらの機能を有す る為にスマート材料あるい恃イテリジェント材料と しての応用が期待されている. 現在まで多くの SMA が開発されているが，疲労強度なよ゙の機機的性質の優 れたTiNi SMA が最も多く実用化されている.

上記の特性を医療分野で応用するために，カテーテ

\footnotetext{
* 原稿受付 2008 年 6 月 23 日.

*1 正員, 愛知工業大学工学部(画 470-0392 䇺田市八草町八千 草 1247).

*2 正員, アイコクアルファ(株)(罗495-8501 稲沢市祖父江町 森上本郷 11-4-1).

*3 学生員, 愛知工業大学大学院工学研究科.

E-mail : tobushi@aitech.ac.jp
}

ルチューブとして SE 細管およびガイドワイヤーとし て高弾性 (highelasticity, HE) 細線が開発されている. ガイドワイヤーとしての HE 細線は㐫力ーひずみ曲線 の直線性と㹨いヒステリシスループ幅，および体内一 の挿入時の高、屈曲抵抗 (high pushability) が要求され る.これらの応用において, SE 細管および HE 細線は 主に平面曲げを受ける. 䀢療度用に执てこれらの素 子は練返し変形を受けるので，それらの安全性と信頼 性を評価寸る上で，材料の疲労特性は非常に重要であ

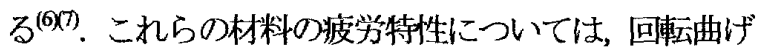
疲労特性は調べられている( ${ }^{(8)}$ が，実際の使用状態に対 応する平面曲げに関寸る疲労特性の研究報告はない．

本研究においては, TiNi 合金の SE 細管および HE 細線の平面曲げ疲労特性を明らかにする.このために， まず材料の基本変形特性として，引張変形特性を示守。 次に，平面曲け疲労特性を調べるために，片振りと両 振りの平面曲け疲労試験を行い，疲労寿命特性を明ら かにする．また，破断面の観察により，疲労き裂の進 
展過程を調べる.さらに，平面曲げと回転曲げの疲労 寿命特性を比較し，両者の関係を明らかにする.なお， TiNi 合金細線の曲け疲労寿命について，空気中での疲 労寿命は液体中での疲労寿命より哑く，また繰返し速 度が高いほど疲労寿命は短い(9). したがって，実際に 体内で使用する場合の疲労寿命は本研究において空気 中での試験で得られる疲労寿命より長くなることを指 摘しておく.

\section{2. 実觔法}

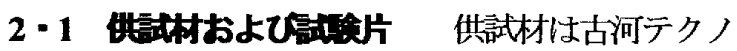
マテリアル株の Ti-50.85at\% Ni 合金て超弾性を示す細 管 NT-E9 (SE-tube) と高弾性を示古細線 FHP-NT (HE-wire) であった. SE-tube の外径は $0.9 \mathrm{~mm}$, 内径は $0.7 \mathrm{~mm}$ であった. HE-wire の外径は $0.5 \mathrm{~mm}$ であった. SE-tube は 803K で2〜3 分間の熱処理により直線形状 を記憶した. HE-wire は高弾性特性を得るために，機 械的に直線状に矯正して作製した．示差走查熱量測定 DSC 試験で求めた SE-tube の変態温度は $M_{s}=311 \mathrm{~K}$, $M_{f}=268 \mathrm{~K}, A_{s}=271 \mathrm{~K}, A_{f}=321 \mathrm{~K}$ であった. HE-wire $の$ 変 態温度については, DSC 試験では明瞭な相変態のピー クは確認できなかった. 試験片は一様形状の細管と細 線であった。試検片の長さは引張試験では 100 $\mathrm{mm} て ゙$ あった. 曲け疲労試験での試験片の長さは 70〜 $150 \mathrm{~mm}$ であり,曲げひずみが大きいほど短い試験片を用いた。

2-2 実基盇 引張試験には形状記憶合金特性 試験装置 ${ }^{(10)}$ を用いた．試験片の変位は標点距離 $20 \mathrm{~mm}$ の伸び諑により測定した。

疲労試験には片振り平面曲け疲労試験装固(11)，雨振

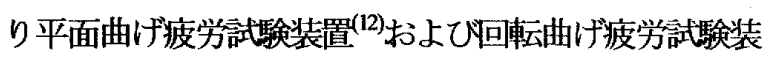
置(9)を用いた．実験では試験片表面の最大曲げひずみ を規定し，一定の繰返し速度で曲げ疲労試験を行い， 破断繰返し数を求めた. 試験片の破断面の観察には走 查電子影微鏡（SEM）を用いた.

2 -3 实:手面 引張試験は一定のひずみ速度の 下で行った.

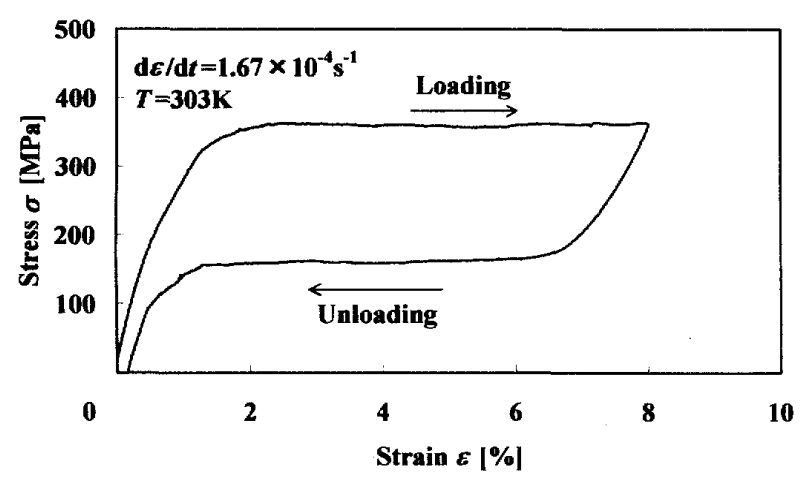

Fig. 1 Stress-strain curve of SE-tube
片振りと両振り平面曲げおよひ回転曲げの疲労試験 は，室温の大気中で行った。試験片は支点間の中央部 で破断した。試験片表面の最大曲げひずみ 部の曲率半径より求めた。繰返し速度 $f$ は $8.33 \mathrm{~Hz}$ (500cpm) とした. 最大曲げひずみに対する最小曲げ ひずみの割合で䙺定されるひずみ比は，片振り平面曲 げでは0であり，両振り平面曲げおよひ回転曲げでは -1である.

\section{3. 実新果およひ考察}

\section{3-1 超弹性管と高㭷性湶の引張㕝柇特性 \\ 3・1・1 超弾性管の底力 - ひずみ開係 超弹} 性細管SE-tubeについて温度 $T=303 \mathrm{~K}$ でひずみ速度 1.67 $\times 10^{-4} \mathrm{~s}^{-1}$ の引張試験で得られた応力－ひずみ曲線を図 1 に示寸. 四 1 からかかるように, 応力ーひずみ曲線 の初期の傾きで定まる弾性係数は35GPaである。この 值は体温においても同じであり，ステンレス鋼の弾性 係数 $190 \mathrm{GPa}$ の 18\%である. したがって，SE-tube の曲 け岡性はステンレス鋼に比べて低く，柔軟性が必要な 医療用力テーテルチェーブの性能に優れている.また, ひずみが 1\%を超えると応力ーひずみ曲線の傾きは小 さくなり，1.5\%を超えると応力水平段が現れる. 水平 段の応力 $\sigma_{\mathrm{M}}$ は $350 \mathrm{MPa}$ である.この応力水平段は応力 誘起マルテンサイト変態 (stress-induced martensitic transformation, SIMT) により現れる.この水平段の态 力 $\sigma_{M}$ の温度 $T$ 八の依存性を表特性值 $C_{M}$ は $C_{M}=$ $\Delta \sigma_{M} / \Delta T=6 \mathrm{MPa} / \mathrm{K}$ であり, 体温では $\sigma_{M}=386 \mathrm{MPa}$ であ る.この $\sigma_{M}$ はステンレス鋼の降伏応力と同じレベルで ある.したがって, SE-tubeでは大きなひずタが一定心 力下で生じるので，曲げによる大きなたわみが容易に 得られる.さらに，除荷過程では応力 $160 \mathrm{MPa}$ の水平 段が逆変態により現れ，ひずみは回復し，超弾性 (SE) の特性を示す.したがって, SE-tube は医療用カテーテ ルチューブに必要な柔軟性およひ形状回復性に優れて いることがわかる，一方，負荷·除荷で応力 - ひずみ曲 線は大きなヒステリシスループを描く．このヒステリ

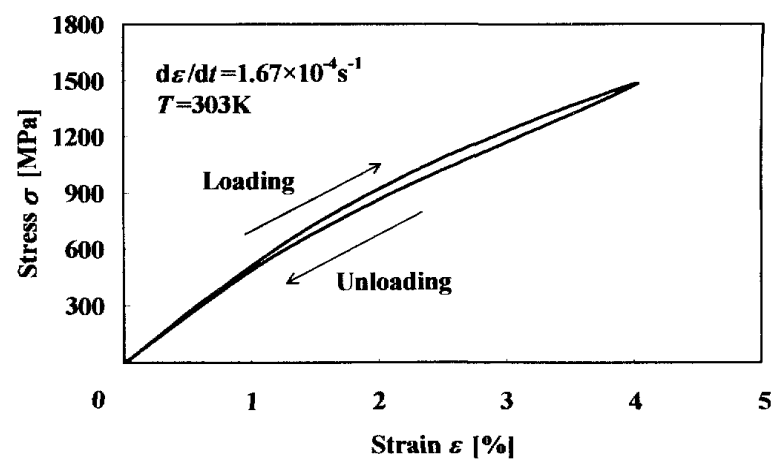

Fig. 2 Stress-strain curve of HE-wire 
シスループで囲まれた部分の面積と除荷曲線の下の面 積は，それぞれ単位体積当りの散冕仕事とひずみ工ネ ルギーを表す．したがって, SE-tube は防振材料および エネルギ一唄葴材料としての機能にも優れている.

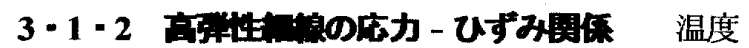
$T=303 \mathrm{~K}$ でひずみ速度 $1.67 \times 10^{-4} \mathrm{~s}^{-1}$ の引張試験により得 られた高弾性細線 HE-wire の応力 -ひずみ曲線を図 2 に示す. HE-wire の応力 -ひずみ曲線は温度およひひ ずみ速度にほとんど依存しない，図2 からわかるよう に，初期の応力 -ひずみ曲線の傾きで定まる弾性係数 は 50GPa である. この值はステンレス鋼の弾性係数 190GPa の26\%である. したがって, HE-wire の曲け剛 性はステンレス銅に比べて低く，柔軟性が必要な医療 用ガイドワイヤーの性能に優れている. また，応力 ひずみ曲線の傾きはひずみが大きくなると徐々に小さ くなるが, 応力 1500MPaでひずみ 4\%まで明膫な降伏 点は現れず，直線からのずれは小さい．また，除荷に よりひずみは回復する.負荷・除荷により応力 -ひずみ 曲線はヒステリシスループを描くが, そのヒステリシ スループの幅は小さい. ガイドワイヤーでは体内人の 挿入時に高い屈曲抵抗を有し，医者の手元での回転操 作に対して患者の体内でガイドワイヤーの先端が同じ 角度で回転すること（この特性はトルク伝達性と呼ば れる）が望ましい：実際に体内で使用する場合の曲げ ひずみは 2\%以下が多い．以上の考察からわかるよう に, HE-wire はこのような医療用ガイドワイヤーに必 要な機能に優れている.

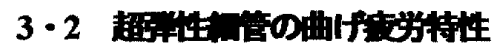

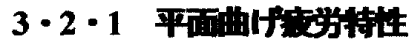

(1) 超弹性紐管 SE-tube の片振り 平面曲げ疲労試験およひ両振り平面曲げ疲労試験によ り得られた最大曲げひずみ $\varepsilon_{\max }$ と破断繰返し数 $N_{f}$ との 関係を図 3 に示す. 本研究では, $N_{f}$ が $1 \times 10^{6}$ 回を超え

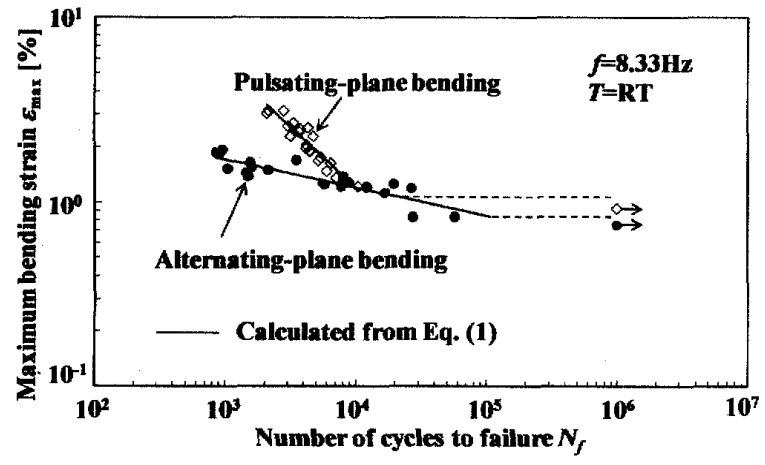

Fig. 3 Relationship between maximum bending strain and number of cycles to failure of SE-tube in plane-bending fatigue
る最大ひずみを疲労限度として扱う。

図 30 疲労寿命曲線からわかるように，低サイクル 疲労域では片振り平面曲げ疲労拉よび両振り平面曲げ 疲労ともに， $\varepsilon_{\max }$ の城少に伴い $N_{f}$ は増大する.片振り 平面曲げ疲労では $N_{f}=1 \times 10^{4}$ 付近で，両振り平面曲げ 疲学では $N_{f}=1 \times 10^{5}$ 付近で疲労寿命曲線に折れ曲がり が現れ，この点以下の $\varepsilon_{\max }$ で $N_{f}$ は急に大きくなる.

低サイクル疲労域の疲労寿命曲線は一定の傾きを持 った直線で近似することができる.したがってこの 疲労寿命曲線は両対数グラフにおいて直線で表される ので， $\varepsilon_{\max }$ と $N_{f}$ との関係は次式で表される.

$$
\varepsilon_{\max } \cdot N_{f}^{\beta}=\alpha
$$

ここで, $\beta$ と $\alpha$ はれれぞれ $\log \varepsilon_{\text {max }}-\log N_{f}$ 曲線の傾きと $N_{f}=1$ での $\varepsilon_{\max }$ の值を表す. 片振り平面曲げ疲労での $\beta$ は 0.66 であり，両振り平面曲げ疲労での $\beta$ は 0.15 であ る.

片振り平面曲げ疲労と雨振り平面曲げ度労において 材料の受ける疲労損傷の特性を考察する.このために， 各々の試験において試験片の表面要素が 1 サイクル中

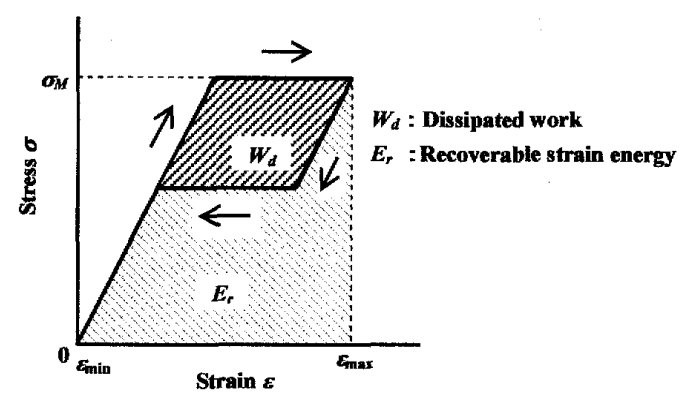

(a) Pulsating-plane bending

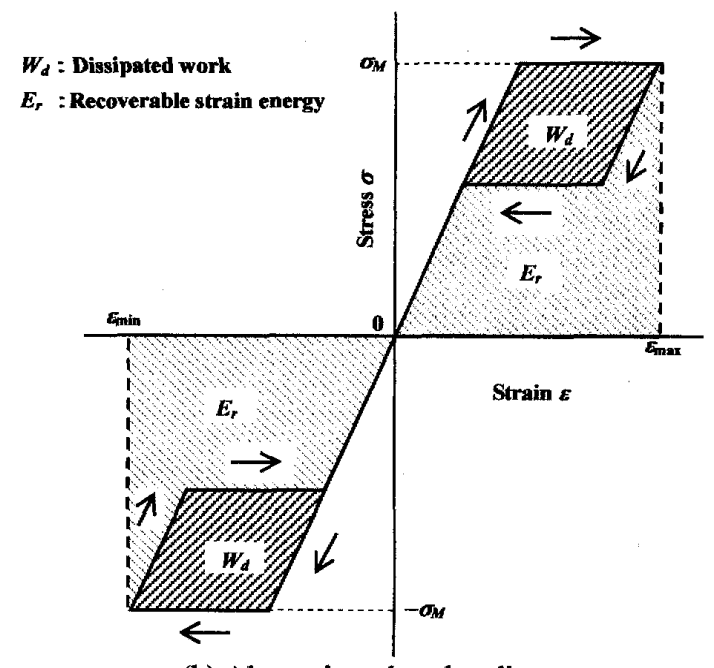

(b) Alternating-plane bending

Fig. 4 Stress-strain diagram of surface element of SE-tube in bending (Dissipated work $W_{d}$ and recoverable strain energy $E_{r}$ ) 
に受ける曲げの応力 -ひずみ線図を図 4 に示す．図 4 では圧縮における応力 -ひずみ関係が引張りの場合と 刘称であることを仮定している(13). 平面曲げでは曲げ た細管の凸側の表面要素には引張応力が，凹側の表面 要素には圧縮応力が作用する．図4に示すように，応 カーひずみ曲線のヒステリシスループで曲まれた面積 は単位体積当りの散冕仕事 $W_{d}$ を表す. 1 サイクルで受 ける $W_{d}$ の值は雨振り平面曲げの方が片振り平面曲げ の 2 倍になる. 繰返し変形を受けると $W_{d}$ により試験 片表面要素の温度は高くなり ${ }^{(14)}$, この為，M変態応力 も高くなり，疲労損傷はより大きくなる.この結果， 片振り平面曲げに比べて両振り平面曲げの方が疲労寿 命が短くなる.この効果は $\varepsilon_{\text {max }}$ が大きいほど大きくな るので, $\varepsilon_{\max }$ が大きくなると疲労寿命の差はより大き くなる. $\varepsilon_{\max }$ が $1.5 \%$ 以下になると，片振り平面曲げと 両振り平面曲げにおける疲労寿命の差は小さくなり， $N_{f}$ はほほ同じ值を示寸. 図 1 て観察された様に，ひず み 1〜1.5\%は応力水平段の開始前であり，忘力ーひず み曲線は直線に近くなり，片振りと両振りのいずれの 場合にも $W_{d}$ は非常に小さい.このため, 疲労損傷に 対する $W_{d}$ の影響は現れず，片振り平面曲げと雨振り 平面曲げで疲労寿命の差は明瞭に現れない。

高サイクル疲労域では疲労寿命曲線は水平段で表さ れる. 疲労限度の $\varepsilon_{\max }$ は片振り平面曲げ疲労では $1.0 \%$ であり，両振り平面曲げ疲労では $0.8 \%$ である. 図 1 の 応力ーひずみ曲線からわかるように，これらのひずみ は SIMT の開始点近傍の值であり，このひずみ以上で 応力 -ひずみ曲線の傾きが小さくなる. したがって, これ以下のひずみでは主に弾性変形であり，SIMT に 基づく $W_{d}$ による疲労損傷は少なく, $N_{f}$ が大きくなる. 疲労限度の詳紐については, さらに多くの実験を行い， 検討する必要がある.

本研究の疲労試験は空気中で $f 8.33 \mathrm{~Hz}$ で行った. TiNi合金細線の曲げ疲労寿命は液体中の方が空気中よ り長く，またfの低いほうが長い，したがって，実際 に体内で使用する場合の疲労寿命は本研究で得られた 疲労寿命より長くなる.

(2) 䂗湎证宗

(i) 片振り平面曲け就学 SE-tube 0 片振り平面 曲け疲労北験により得られた破断面のSEM写真を図 5 に示す．図 5(a)，(b)，(c)はそれぞれ破断面の全体図， 疲労き裂起点部の拡大四, 最終破断部门桩大図を示寸。 この写真は $\varepsilon_{\max }=1.38 \%, N_{f}=53494$ で得られた破断面で ある。

図 5(a)からわかるように，曲げひずみが最大になる 外表面から疲労き裂が発生し，内表面まで貫通し，そ
の後最終破断が円周に沿って两側で進展する. 図 5(a), (b)からわかるように，疲労き裂は外表面の一点から発 生し，き裂の起点部から放射線状に進展し，き裂長さ $120 \mu \mathrm{m}$ の位置に疲労き裂准展領域と最終破断領域の扇 形の境界がある.SMA 細線の平面曲げ度労の破断面で は同様の外表面からの扇形の疲労き裂進展領域力゙明膫 に観察される(15). 図 5(c)からわかる上うに，最終破断

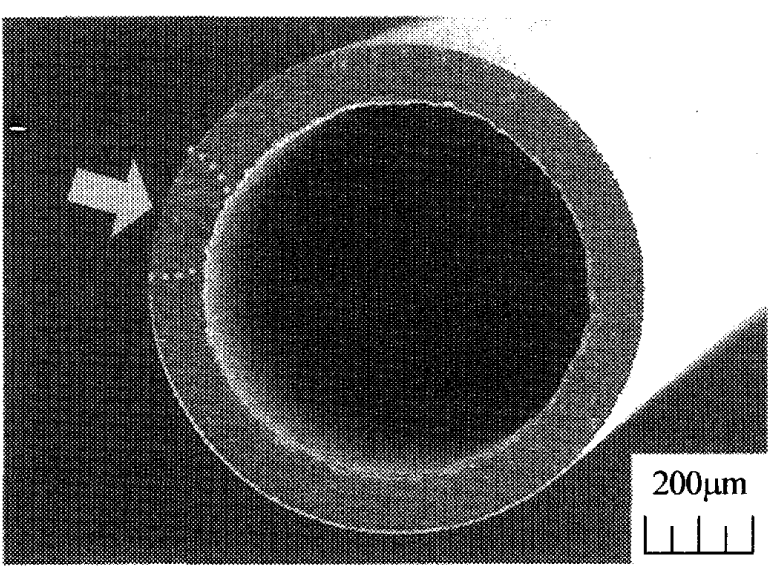

(a) Whole fracture surface

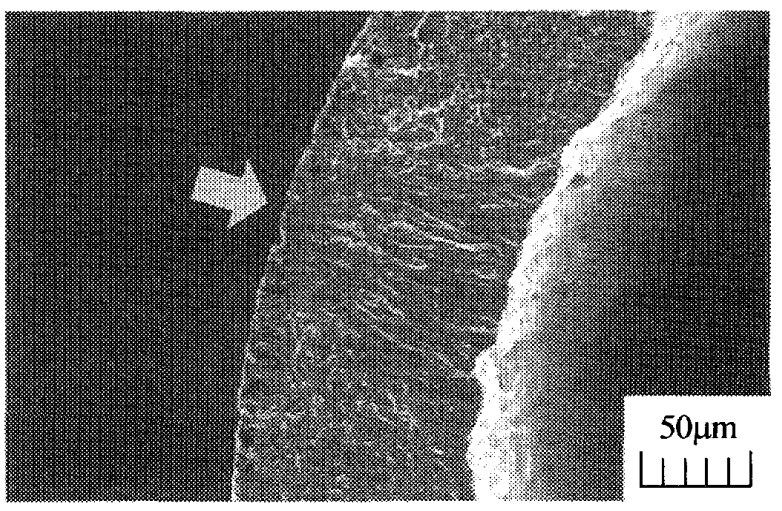

(b) Fracture surface of fatigue-crack initiation part

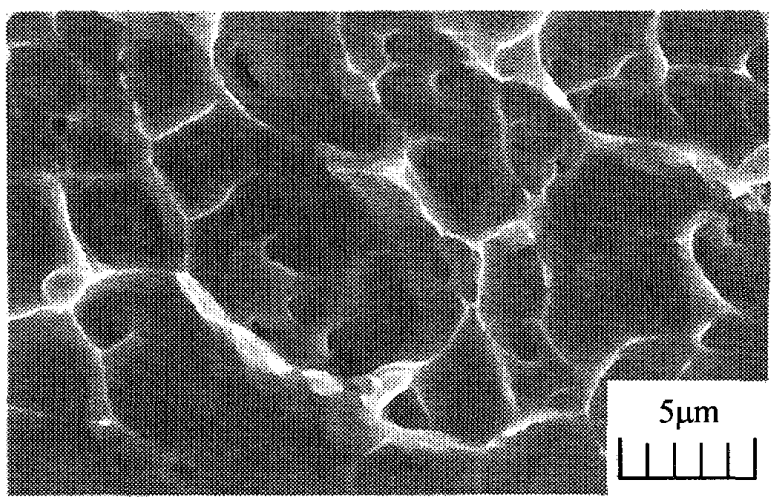

(c) Fracture surface of unstable fracture

Fig. 5 SEM photographs of fracture surface for SE-tube in pulsating-plane bending fatigue 
部では直径 1～5 $\mu \mathrm{m}$ のディンプルが確認できる.

(ii) 两振り平面曲け交学 SE-tube の両振り平面 曲げ疲労試験により得られた破断面のSEM写真を図6 に示古．図6(a)，(b)，(c)はそれぞれ破断面の全体図， 疲労き裂起点部の搪大図, 最終破断部の航大図を示す。 この写真は $\varepsilon_{\max }=1.05 \%, N_{f}=7078$ で得られた破断面で ある.

図 6(a)加わかるように，疲労き裂は内表面加発 生し，外表面まで貫通し，その後最終破断が円周に沿 って両側で進展する. 図6(a),(b)からわかるように, 疲

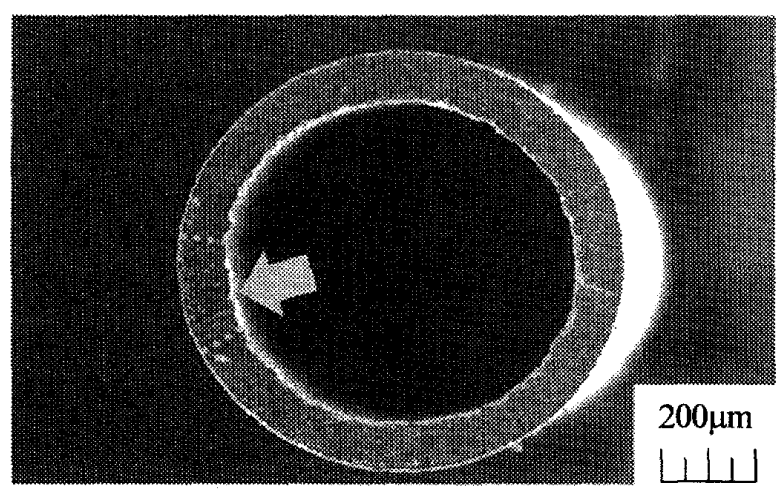

(a) Whole fracture surface

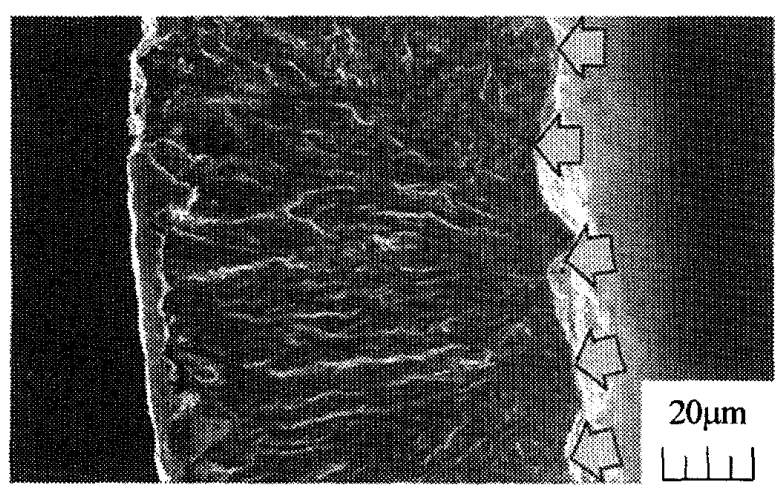

(b) Fracture surface of fatigue-crack initiation part

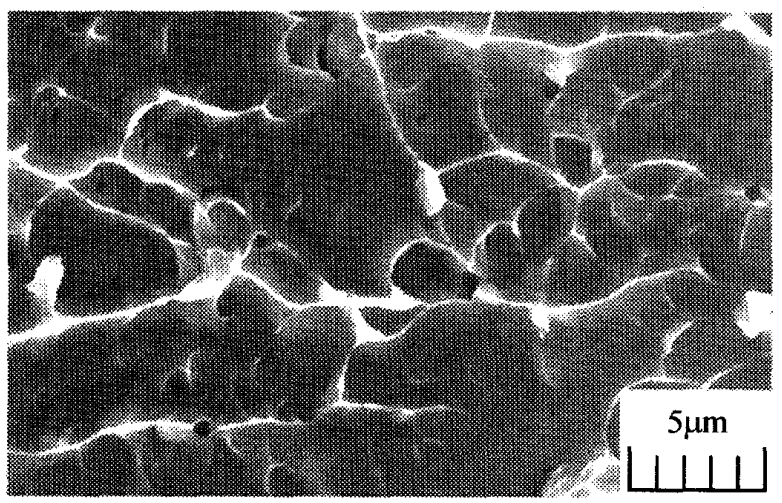

(c) Fracture surface of unstable fracture

Fig. 6 SEM photographs of fracture surface for SE-tube in alternating-plane bending fatigue
労き裂は内表面の一点ではなく幅 $200 \mu \mathrm{m}$ の範囲で多 数発生し，外表面に向からて進展する. 両振り平面曲 げにおいて疲労き裂が内表面から発生し外表面に向か って進展する過程は，図 5 て観察された片振り平面曲 げにおいて疲労き裂が外表面から発生し内表面に向か って進展する過程と異なる，两振り平面曲げにおける 疲労き裂の内表面功の発生と外表面一の進展の過程 は，回転曲げにおける疲労き裂の発生と進展の過程と 同じである ${ }^{(8)}$ ，雨振り平面曲げでは回転曲汭同椂に ひずみ比は-1 である. 疲労き裂が内面で発生するのは, 内表面の粗さに起因している. 細管の成形において, 内側は拘束されていない為に内表面は粗い，細管の軸 方向に沿って測った十点平均粗さは外表面では $3.4 \mu \mathrm{m}$, 内表面では $11.2 \mu \mathrm{m}$ である. 内表面の方が約 3 倍粗く, 内表面の要素では局所的な応力集中がより大きくなる. この為, ひずみ比-1で引張りと圧縮の曲げ㐫力を交互 に繰返し受ける両振り平面曲げと回転曲げの場合，疲 労き裂は内表面で発生するものと考穴られる．したが って，雨振り平面曲げと回転曲げの疲労寿命を長くす るためには，細管の内表面の粗さを小さくする成形法 を開発する必要がある.

図 6(c)からわかるように，最終破断部ではディンプ ルが確認でき，雨側から進展してきた破面が出会った 所で段差が現れる.

\section{$3 \cdot \mathbf{2} \cdot 2$ 平面曲げと回転曲げの夜労寿命の比较}

図3に示した片振りと両振りの平面曲げ度労試験で得 られた疲労寿命曲線と回転曲げ疲労圾験で得られた疲 労寿命曲線を同時に図 7 に示寸. 図 7 の疲労寿命曲線 は最大曲げひずみ $\varepsilon_{\max }$ と破断繰返し数 $N_{f}$ との関係で整 理してある.

図7からわかるように，低サイクル疲労域において は片振り平面曲げの疲労寿命に比べて両振り平面曲げ と回転曲げにおける疲労寿命は短く, $\varepsilon_{\text {max }}=2 \%$ では片振

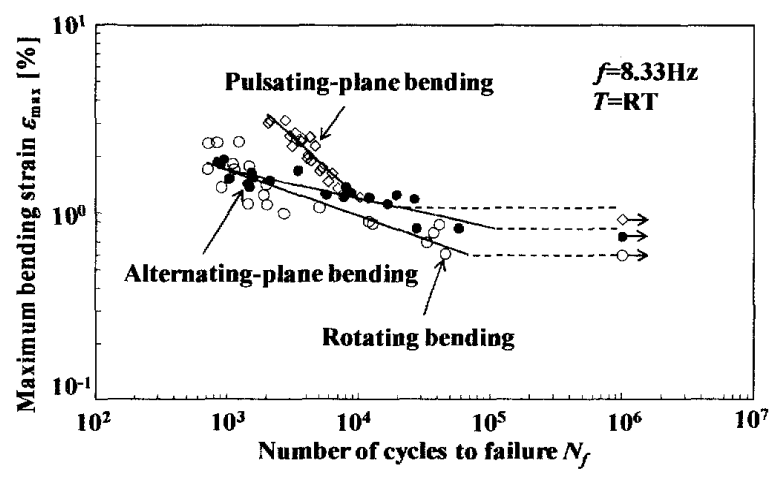

Fig. 7 Relationship between maximum bending strain and number of cycles to failure of SE-tube in plane-bending and rotating-bending fatigues 
り平面曲げでの疲労寿命は約 5 倍長い，ひずみ比は片 振り平面曲げ度労では 0 であり，両振り平面曲げ疲労 と回転曲け疲労では-1 である. 両振り平面曲げ疲労と 回転曲げ度労では細管の表面要素は引張応力と圧縮心 力を交互に受け,このために疲労寿命は短くなる. TiNi SMAの超弾性細線では $\varepsilon_{\max }$ が大きくなると両振り平面 曲げに比べて回転曲げ疲労の寿命の方が若干短くなる 傾向にある゙ ${ }^{(1)}$. 図7のSE-tubeについては， $\varepsilon_{\max }$ の小さ い範用で回転曲げの疲労寿命が短い，回転曲げ度労で は全円周の表面要素が絽返し SIMT を受けるので, 試 験片の温度上昇が大きくなり，対応して変態応力も高 くなり，疲労損傷が大きく， $N_{f}$ は小さくなると考えら れる. $\varepsilon_{\max }$ が大きくなると疲労寿命は短くなり，雨振 り平面曲げと回転曲げの疲労寿命に明瞭な差は現れな くなる. 図 7 において, 3 種類の疲労寿命のばらつき を比較すると，回転曲げと両振り平面曲げでのばらつ きが大きい，回転曲げと両振り平面曲げでは内表面か ら疲労き裂が発生する.これは内表面の粗さに起因し ており，表面粗さは不均質である。このため，疲労き 裂の発生は一様ではなく, 疲労寿命のばらつきが大き くなると考えられる.

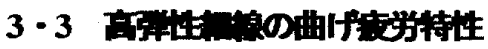 \\ $3 \cdot 3 \cdot 1$ 平面曲依学特性}

(1) 学学素命特性 高弹性紐線 HE-wire の片振り 平面曲げ疲労試験および両振り平面曲げ疲労試験によ り得られた最大曲げひずみ $\varepsilon_{\text {max }}$ と破断繰返し数 $N_{f}$ との 関係を図8に示寸.

図 8 の疲労寿命曲線からわかるように，低サイクル 疲労域では片振り平面曲げの疲労寿命の方が両振り平 面曲げの疲労寿命より長い.いずれの場合にも， $\varepsilon_{\max }$ の减少に伴い $N_{f}$ は増大寸る. 片振り平面曲げ疲労試験 では $N_{f}=4 \times 10^{4}$ 付近で，両振り平面曲げ疲労では $N_{f}=2$ $\times 10^{4}$ 付近で波労寿命曲線に折れ曲がりが現れ，この点

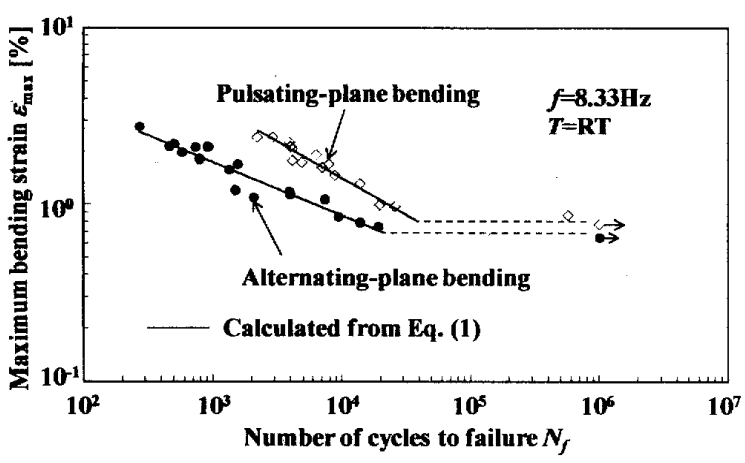

Fig. 8 Relationship between maximum bending strain and number of cycles to failure of HE-wire wire in plane-bending fatigue
以下の $\varepsilon_{\max }$ で $N_{f}$ は急に大きくなる.

低サイクル疲労域の疲労寿命曲線は一定の傾きを持 った直線で近似することができる．したがって， $\varepsilon_{\max }$ と $N_{f}$ の関係はSE-tube の場合と同様に式(1)で表すこと ができる，直線の傾きを表す $\beta$ は片振り平面曲げ疲労 では0.41であり, 両振り平面曲げ疲労では0.30である.

高サイクル疲労域では疲労寿命曲線は水平段で表さ れる. 疲労限度 $\boldsymbol{\varepsilon}_{\max }$ は片振り平面曲け疲労では $0.8 \%$ であり，両振り平面曲げ疲労では $0.7 \%$ である. 図 3 で 示した SE-tube の疲労限度に比べて HE-wire $の$ 疲労限 度の $\boldsymbol{\varepsilon}_{\max }$ は, 片振り平面曲げと雨振り平面曲げでそれ ぞれ 0.2\%と 0.1\%小さい.この理由は次のように考え られる. 図 1 と図2 の応力ーひずみ曲線で示したよう に, HE-wire の疲労限度の $\varepsilon_{\max }$ は線形弾性の範用にあり， 同じ $\varepsilon_{\max }$ では度力が高い.このために HE-wire では小 さい $\varepsilon_{\max }$ でも高い応力による疲労損傷が大きい. した がって, HE-wire の疲労限度の $\varepsilon_{\max }$ の方が小さくなる.

図 8 において疲労寿命曲線を比較すると，片振り平 面曲げ疲労の曲線が雨振り平面曲げ疲労の曲線の上側 (長寿命側) に位置する. 図4 の态力 -ひずみ線図で 示した様に，両振り平面曲げでは線材の表面要素には 引張応力と圧縮応力が交互に作用する．1 サイクルに おける応力ーひずみ曲線から規定されるひずみ変動幅 $\Delta \varepsilon=\varepsilon_{\max }-\varepsilon_{\min }$ は片振り平面曲げ疲労に比べて雨振り平 面曲け疲労の方が 2 倍大きい，したがって，両振り平 面曲け疲労の方が疲労損傷が大きく，短寿命になる. この為に, 両振り平面曲け疲労の疲労寿命曲線は下側 (短寿命側)に位置寸る.

HE-wire の応力 -ひずみ曲線は温度およびひずみ速 度にほとんど依存しない，したがって，本研究で得ら れた空気中で $f=8.33 \mathrm{~Hz}$ における疲労寿命特性は実際に 体内で使用する場合の疲労寿命特性と同じになる.

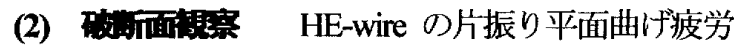
試験により得られた破断面のSEM 写真を図9に示す。 図 9(a)，(b)，(c)はそれぞれ破断面の全体図，疲労き裂 起点部の拡大図，最終破断部の拡大図を示寸．この写 真は $\varepsilon_{\max }=1.5 \%, N_{f}=4846$ で得られた破断面を示寸.

図 9(a)からわかるように，曲げひずみが最大になる 表面の一点から疲労き裂が発生し，疲労き裂は扇形に 進展し，最終破断寸る. 図9(a),(b)功わかるように, 疲労き裂は扇形に進展し，き裂長さ $100 \mu \mathrm{m}$ で最終破断 寸る. 図 9(c)からわかるように, 最終破断部では直径

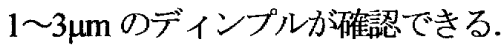

両振り平面曲げ度労およひ回転曲け疲労についても, 疲労き裂は表面の一点加発生し, 扇形に進展し，最 終破断する(8). 


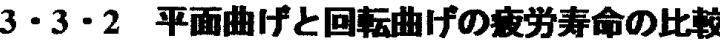

図 8 に示した片振りと両振りの平面曲け疲労試呀で得 られた疲労寿命曲線と回㧫曲げ疲労試験で得られた疲 労寿命曲線を同時に図 10 に示寸. 図 10 \%疲労寿命曲 線は最大曲げひずみ $\varepsilon_{\max }$ と破断綝返し数 $N_{f}$ との関係で 示寸.

図 10 からわかるように, 片振り平面曲げ度労に比心゙ て両振り平面曲け疲労と回転曲け疲労の $N_{f}$ は小さく,

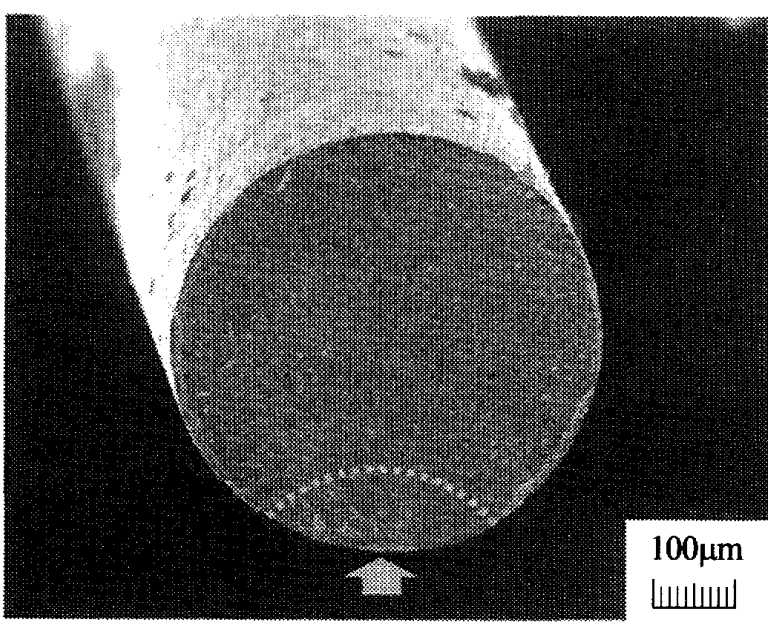

(a) Whole fracture surface

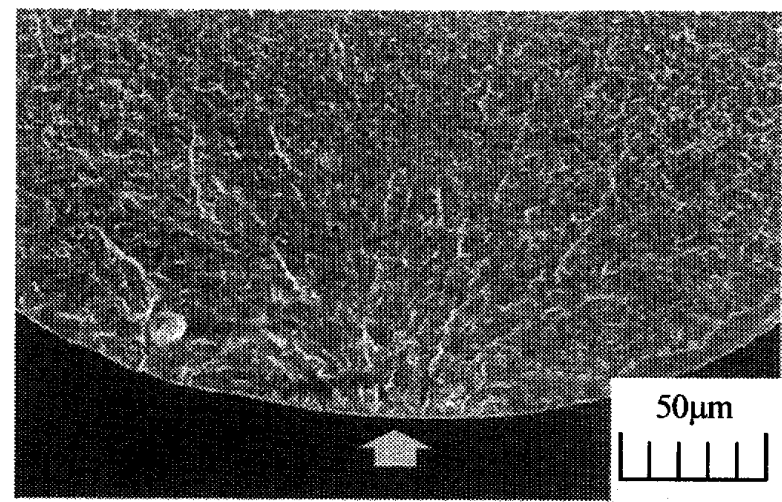

(b) Fracture surface of fatigue-crack initiation part

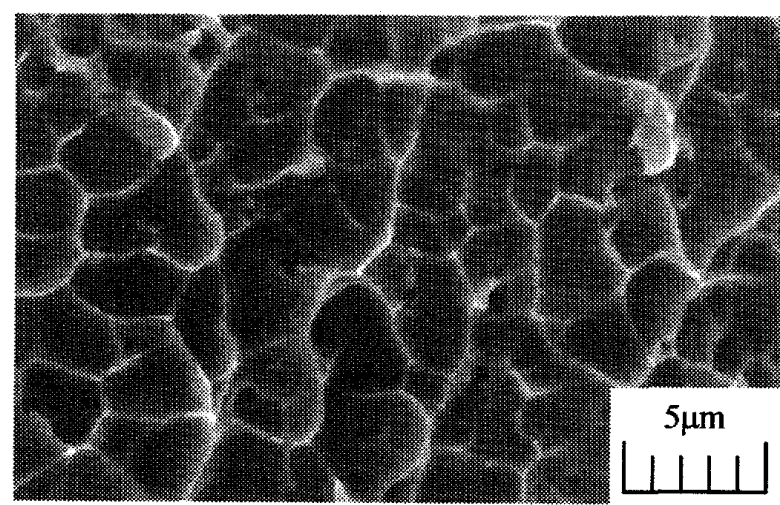

(c) Fracture surface of unstable fracture

Fig. 9 SEM photographs of fracture surface for $\mathrm{HE}$-wire in pulsating-plane bending fatigue $\varepsilon_{\max }=2 \%$ では片振り平面曲げでの疲労寿命は約 10 倍長 い.また，両振り平面曲げと回転曲げ紴労における疲 労寿命はほほ同じになる. 両振り平面曲げと回転曲げ ではひずみ比が共に-1 であり，試験片表面要素には引 張応力と圧縮応力が交互に作用する。このように表面 要素は引張りと圧縮の変形を繰返し受けるため, 両者 の披労寿命はほぼ同じになる． $\varepsilon_{\max }$ が大きくなると回 転曲げの $N_{f}$ のほうが若干小さくなる傾向にある。この 傾向は TiNi SMA の超弾性紐線でも現れる ${ }^{(15)}$. 回転曲 げ疲労では全円周の表面要素が同じ変形履歴を受け， $\varepsilon_{\max }$ が大きくなると疲労き裂の進展が容易になり， $N_{f}$ が小さくなると考えられる.

\section{4. 结言}

TiNi 合金の超弾性細管 (SE-tube) および高弹性細線 (HE-wire) の引張変形特性执よび片振りと両振りの平 面曲げおよび可転曲げの疲労特性を実験的に調べた。 得られた主要な結果は次の通りである.

(1) 引張りに拉ける SE-tube の応力 - ひずみ曲線は負 荷·除荷でヒステリシスループを描き超弾性を示 す. 弾性係数は $35 \mathrm{GPa}$ であり, ステンレス鋼のそ れと比べて小さい，したがって，SE-tube は医療 用カテーテルチューブに必要な柔軟性と形状回 復性に優れている. HE-wire の忘力 - ひずみ曲線 はひずみ $4 \%$, 応力 $1500 \mathrm{MPa}$ まで直線に近く，負 荷·除荷でのヒステリシスループの幅が狭い，弾 性係数は 50GPaである. したがって，HE-wire は 医療用ガイドワイヤーに必要な柔軟性，挿入時の 高屈曲抵抗执びトルク伝達性に優れている.

(2) SE-tube の疲労寿命曲線を最大曲げひずみ $\varepsilon_{\text {max }}$ と 破断繰返し数 $N_{f}$ の関係で表すと,いずれの曲げ疲 労においても，低サイクル疲労域の $\varepsilon_{\max }$ と $N_{f}$ の関 保はべき関数で表される.ひずみ比 0 の片振り平 面曲げの疲労寿命は長く,ひずみ比-1 の両振り平

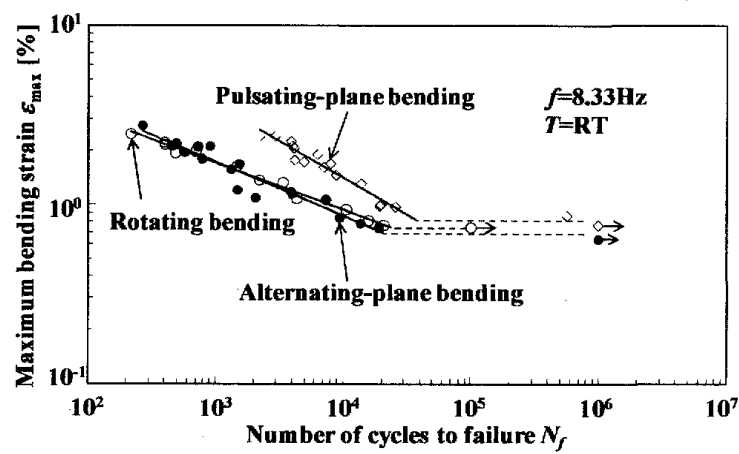

Fig. 10 Relationship between maximum bending strain and number of cycles to failure of HE-wire in plane-bending and rotating-bending fatigues 
面曲げと回転曲げの疲労寿命は短い，両振り平面 .曲げと回転曲げの疲労寿命の差異は小さい. 疲労 限度の最大曲げひずみは SIMT 開始点近傍の 0.8 〜 1.0\%である. SE-tube を実際に体内で使用する 場合の疲労寿命は, 本研究で得られた疲労寿命よ り長くなる. 疲労き裂は片振り平面曲げ疲労では 外表面の一点加発生し, 内表面に貫通後に最終 破断する. 回転曲げ度労および両振り平面曲げ疲 労では，疲労き裂は内表面の幅 $200 \mu \mathrm{m}$ の範周で 多数発生し, 外表面に貫通後に最終破断する.

(3) HE-wire の疲労寿命については, 片振り平面曲げ の疲労寿命が脣く, 両振り平面曲げの疲労寿命と 回転曲げの疲労寿命は短い. 雨振り平面曲げと回 転曲げの岥労寿命の差異は小さい.いずれの曲げ 疲労においても，低サイクル疲労域の $\varepsilon_{\max }$ と $N_{f}$ の 関係はべき関数で表され，疲労限度の最大曲げひ ずみは 0.7〜0.8\%である. HE-wire を実際に体内 で使用する場合の疲労寿命は，本研究で得られた 疲労寿命と同じになる. 片振り平面曲げ疲労, 両 振り平面曲げ疲労および回転曲げ疲労のいずれ の場合にも，疲労き裂は外表面の一点から発生し， 扇形に進展し，最終破断する.

終わりに，本研究を行うに当り，実験に協力された 愛知工業大学の学生諸君に感謝する. また, 本研究の 一部は日本学術振興会・科学研究費補助金・基盤研究 (C)の補助を受けたことを記し，謝意を表す。

\section{考文视}

(1) Funakubo, H, ed, Shape Memory Alloys, (1987), Gordon and Breach Science Pub., New York.

(2) Duerig T. W., Melton, K. N., Stockel, D. and Wayman, C. M., eds., Engineering Aspects of Shape Memory Alloys, (1990), Butterworth-Heinemann, London.

(3) Saburi, T, ed, Shape Memory Materials, (2000), Trans Tech Pub., Switzerland.

(4) Chu, Y. Y. and Zhao, L. C., ed, Shape Memory Materials and Its Applications, (2002), Trans Tech Pub., Swizerland.

(5) Otsuka, K. and Wayman, C. M., ed., Shape Memory Materials, (1998), Cambridge University Press, Cambridge.

(6) McKelvey, A. L. and Ritchie, R. O., Fatigue-Crack Growth Behavior in the Superelastic and Shape-Memory
Alloy Nitinol, Metall. Mater. Trans. A, Vol. 32A, (2001), pp. 731-743.

(7) Sawaguchi, T,, Kaustrater, G., Yawny, A., Wagner, M. and Eggeler, G., Crack Initiation and Propagation in 50.9 At. pct Ni-Ti Pseudoelastic Shape Memory Wires in Bending-Rotation Fatigue, Metall. Mater. Trans. A, Vol. 34A, (2003), pp. 2847-2860.

(8) Matsui, R., Tobushi, H., Furuichi, Y. and Horikawa, H., Tensile Deformation and Rotating-Bending Fatigue Properties of a Highelastic Thin Wire, a Superelastic Thin Wire, and a Superelastic Thin Tube of NiTi Alloys, Trans. ASME, J. Eng Mater. Tech, Vol. 126, (2004), pp. 384-391.

(9) Tobushi, H., Hachisuka, T, Hashimoto, T. and Yamada, S., Cyclic Deformation and Fatigue of a TiNi Shape-Memory Alloy Wire Subjected to Rotating Bending Trans. ASME, J. Eng. Mater. Tech., Vol. 120, (1998), pp. 6470.

(10) Tobushi, H., Tanaka, K., Kimura, K., Hori, T. and Sawada, T., Stress-Strain-Temperature Relationship Associated with the R-Phase Transformation in TiNi Shape Memory Alloy, JSME Inter. J., Ser. L, Vol. 35, No. 3,(1992), pp. 278-284.

(11) Tobushi, H., Okumura, K. and Takata, K, Fatigue Properties of TiNi Shape Memory Alloy, Trans. Mater. Res. Soc. Jap., Vol. 26, No. 1, (2001), pp. 347-350.

(12) Funuichi, Y. Tobushi, H. and Matsui, R., Fatigue Properties of TiNi Shape-Memory Alloy Wire in Bending, Trans. Mater. Res. Soc. Jap., Vol. 28, No. 3, (2003), pp. 615-618.

(13) Hashimoto, K., Tokuda, M., Inaba, T., Shioda, A., Sittner, P. and Bundara, B., Experimental Research on Deformation of Ti-Ni SMA under Complex Loading Conditions, Key Eng. Mater., Vols. 233-236, (2003), pp. 547-552.

(14) Mikuriya, S., Nakahara, T., Tobushi, H. and Watanabe, H., The Estimation of Temperature Rise in Low-Cycle Fatigue of TiNi Shape Memory Alloy, JSME Inter. J., Ser. A, Vol.43, No. 2,(2000), pp. 166-172.

(15) Matsui, R., Makino, Y., Tobushi, H., Furuichi, Y. and Yoshida, F., Influence of Strain Ratio on Bending Fatigue Life and Fatigue Crack Growth in TiNi Shape-Memory Alloy Thin Wires, Mater. Trans., Vol. 47, No. 3, (2006), pp. 759-765. 